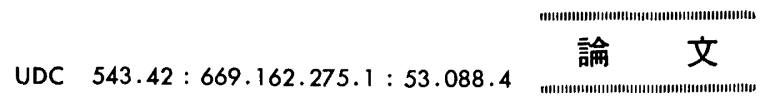

\title{
銑鉄のカントバック分析における異常放電と その分析值におよぼす影響*
}

\author{
成田 貴一**。松村 哲夫***. 徳田 利幸**** \\ 諸岡 錬平 $* * * *$. 野々村英造 $* * * *$
}

\section{An Unusual Discharge Phenomenon and Its Effect on Pig Iron Analysis by Vacuum Emission Spectrometry}

Kiichi Narita, Tetsuo Matsumura, Toshiyuki Tokuda,

Renpei MOROoKA, and Eizo Nonomura

Synopsis :

In vacuum emission spectrometric analysis of pig iron by D. C. low voltage spark excitation in argon, an unusual or improper discharge, whose symptoms are a prolonged integration time and whitishlooking burn marks on the sample surface, is encountered on apparently good sound samples and gives seriously erratic results.

The experiment showed that under the discharge in question the samples sparked with an integration time between 5 and 30\% longer than normal and that the negative errors of $0.04 \%$ silicon, $0.025 \%$ manganese, and $0.02 \%$ phosphorus were common. The exception was sulfur but the results were less reproducible.

An optical and electron microscopic study of the sample surface and burn marks revealed that the improper excitation was caused owing to a preferential sparking to flakes of graphite.

A detailed study of the analytical conditions was carried out and it was found that a long pre-spark of 60 seconds altered the spark characteristics and improved the analytical accuracy and precision to a considerable extent.

Some important problems associated with the spectrometry, i. e., the distribution of excited atoms in the analytical gap and the selection of internal standard lines, were also investigated and discussed.

(Received Mar. 4, 1974)

\section{1. 緒言}

転炉製鋼における溶銑成分の分析は吹錬条件の決定, 吹止め時における適中率の向上などの点から非常に重要 な分析の一つである.

製鉄業におけるこの種の分析は周知のようにカントバ ック分析に代表される機器分析により行なわれている. この場合, 溶銑試料のカントバック分析は溶鋼試料の分 析に比較し多くの解决しなければならない問題を含んで いる. とくに分析試料の採取における試料の白銑化の問 題は非常に重大であり，これに起因する現象は分析過程 において致命的な欠陥をもたらすことがある.

この問題については採取鋳型の形状，チル化促進剤の 添加などによる方法が報告されている1）6が，いずれの 方法も限定された成分範囲の材料のみに有効であり, 実 作業へ適用するまでにはいたつていない.
そこで本報告ではカントバック分析の異常放電機構な らびにそれに起因する分析上の問題点について検討を行 なつた結梁を述べる。

\section{2. 実 験 方 法}

\section{$2 \cdot 1$ 実験装置}

（1）光電測光式発光分光分析装置

島津製真空型カントレコーダー GV-200

ARL 製真空型カントメーター 13000

（2）走査型電子顕微鏡

日立製走查型電子顕微鏡 HSM-2

* 昭和 48 年 10 月日本金属学会秋期大会にて一部 発表

昭和 49 年 3 月 4 日受付

** (株) 神戸製鋼所中央研究所理博, 工博

*** (株) 神戸製銅所中央研究所工博

$* * * *$ (株) 神戸製鋼所中央研究所 
(3) X線マイクロアナライザー

\section{島津製 EMX-SM 型}

\section{2 正常放電亡異常放電の比較}

溶銑試料の放電過程において放電の異常性を判断する 因子として積分時間と放電痕の観察がある.これらは経 験的によく知られていることであるが，その異常放電の 原因，あるいは発生機構と積分時間の増大や放電痕の性 状との関係についてはじゅうぶんに解明されていない.

そこで日常分析試料を正常, 異常放電試料に分類し, 試料の表面状況，金属組織などについての観察を行なう ことにした.

また Si，Mn，P，S の4 元素を対象に正常, 異常放 電試料を分析し，異常放電が分析値にあたえる影響の種 類, 程度について調查した。

さらに放電状況（積分時間）を監視し，異常放電に起 因する分析誤差を定量的に評価する方法についても検討 した.

\section{3. 実 験 結 果}

\section{1 銑鉄のカントバック分析における異常放绳現象}

$3 \cdot 1 \cdot 1$ 分析試料の欠陷之異常放電

銑鉄のカントバック分析には一般に直流高圧スパーク 法が適用されるが，当社では同一装置を鋼の分析にも使 用する場合があるため，直流低圧スパーク (DG LVS) 法を採用している.したがつて，本実験はすべて LVS 法によつたもので, 励起条件としては二次電圧 $1 \mathrm{kV}$, 静電容量 $6 \mu \mathrm{F}$, 自己誘導 $50 \mu \mathrm{H}$ ，二次抵抗 $5 \Omega$ の臨界 減衰放電条件を使用した.

銑鉄のカントバック分析用の試料としては偏析のな い，良好な白銑組織のものが要求され，金型中に溶銑を 鋳込えで急泠して採取しているが実際上はつねに満足な 試料を得ることは容易ではない。

カントバック分析における試料の正常, 異常の判定は 内標準線として使用する $\mathrm{Fe}$ のスペクトル線強度が一定 強度に達するに要する時間（積分時間）の監祝, および 試料面に生成する放電痕の観察によつて行なわれる.

前者については規定積分時間のある限界を越えるも の, 後者では放電痕の外周に黒褐色の輪状物 (black ring または brown ring と呼ばれる) の生成のないものが異 常放電を起こしたと判定される．このような場合には不 正確な分析值が得られるので，不良試料として萧却され る.

これら不良試料のうち, 的 $40 \%$ はクラック, ピンホ ールなどによるものであり，他の約 60\% の試料は外観 上，陌は認められないものであることがわかつた。
なお，このような正常，異常放電において観察される

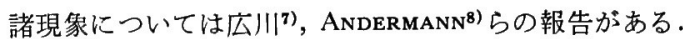

$3 \cdot 1.2$ 異常放電試料の観察結果

異常放電はクラック，ピンホールなどの原因によつて も生じる。しかしながらこれらの原因によるものは肉眼 で容易に判定できるので，この種の異常放電試料を除外 して正常，異常放電試料を比較検討した.

正常，異常放電試料を肉眼で注意深く観察すると，異 常放電試料には白く罴つた部分が多数認められるのに対 し，正常放電試料ではそれらの部分は非常に少ないか， あるいはまつたく認められない。

そこでこの白く曇つた部分を顕微鏡で観察すると，異 常組織部が認められた. その一例を Photo. 1 に示す.

正常，異常放電試料ともにマトリックスはレデブライ ト組織である。 また初晶セメンタイトの析出量について は材料により差を認めるが，この析出量の差で正常, 異 常放電試料を分類することはできなかつた。

Photo. 1 に示す異常組織を明確にするため, EMX により同定した結果，異常組織はグラフォイトであるこ
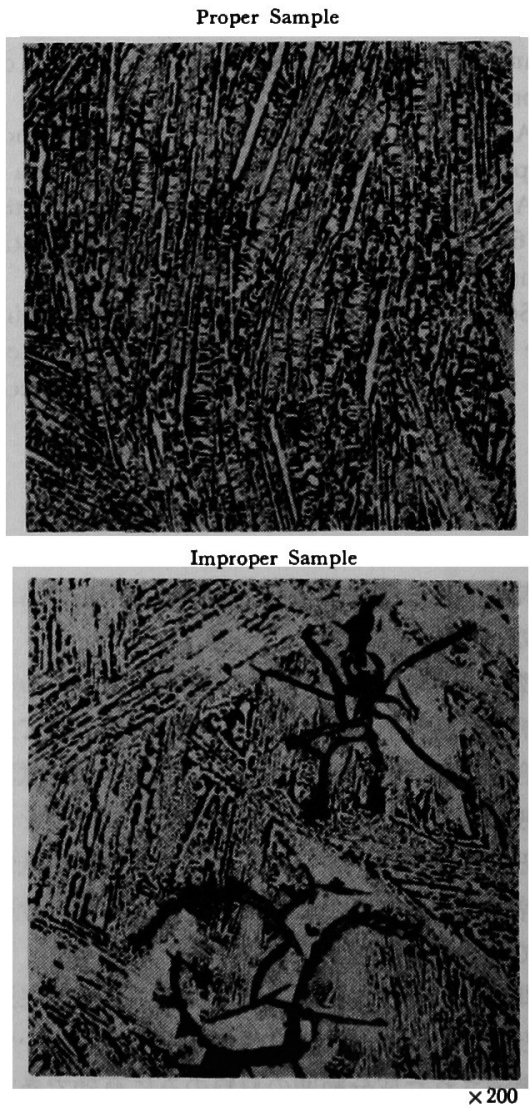

Photo. 1. Comparison of sample surface. 
Table 1. Content of graphite in proper and improper samples. (\%)

\begin{tabular}{|c|c|c|c|}
\hline Kind & 1 & 2 & 3 \\
\hline $\begin{array}{l}\text { Proper sample } \\
\text { Improper sample }\end{array}$ & $\begin{array}{l}0.28 \\
0.54\end{array}$ & $\begin{array}{l}0 \cdot 19 \\
0 \cdot 95\end{array}$ & $\begin{array}{l}0.07 \\
0.67\end{array}$ \\
\hline
\end{tabular}

とを確認した．また正常，異常放電試料の区別はこのグ ラフォイト組織の顕微鏡観察で可能であるので，異常放 電の原因がグラファイトに起因するものと判断した.

つぎ，異常放電とグラフォイト量の関係を調べるた め, 正常, 異常放電試料から各 3 試料を抜き取り, グラ ファイトの分析を行なつた.

分析試料は分析面より厚さ約 $3 \mathrm{~mm}$ の円板を切り出 し，これを破砕して調製した. Table 1 にその分析結果 を示す。

この結果は放電面に存在するグラファイト量であると はいえないが，異常放電試料は明らかに高値を示してい る.したがつて少なくとも $0.5 \%$ 以上含有する試料では 異常放電を発生すると考えるべきであろう。

本実験で観察されたグラファイトは冷却速度を考虑す ると，凝固後 $\left(720^{\circ} \mathrm{C}\right)$ のオーステナイトの分解により 生じた二次グラフォイトであるうと判断される.

\section{$3 \cdot 1 \cdot 3$ 放電時におけるグラフォイトの影響}

グラフォイトの存在と異常放電との関係を明らかにす る目的で，走査型電子顕微鏡による放電痕の観察を行な つた. 供試料は鏡面研摩後 $2 \mathrm{sec}$ 放電させた. Photo. 2 に放電による侵食の比較的少ない放電痕周辺部の顕微鏡 写真を示す. 写真は明らかにグラフォイト周辺において 選択放電が生じていることを示している。選択放電とい われる現象の機構はまだじゅうぶんには解明されていな い. 萩原らの) は試料面の山凸に起因する電界分布の乱れ

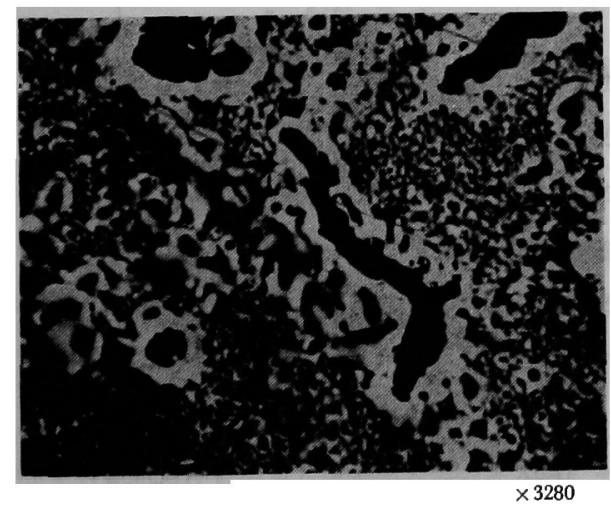

Photo. 2. Electron micrograph of preferential sparking around graphite flakes.
あるいは異種物質の境界に生ずる接触電位差によるもの であるうとしている. しかし，この問題についての結論 は本実験では得られなかつた，しかしながらこの観察結 果から，グラフォイトの存在と異常放電との現象面での 関係はある程度推定することが可能である.すなわち， グラファイトが多数存在する場合には放電のストリーマ 一がその周辺部へと選択的に分散するため，放電は集中 的とならずスペクトル線強度の弱い拡散的な異常放電に なると考えられる.

\section{1 .4 正常および異常放電時の放電痕}

正常放電をした場合の放電痕には外周部に黒褐色のい わゆる black ring が発生するのが特徴的で, これに対 乙異常放電痕にはそれがほとんど認められず，その部分 は乳白色を呈し, 中心部の侵食の程度は正常放電痕に比 較して少ない。

中心部については明らかに放電時の侵食によるものと 考えられたので, 正常, 異常放電を特徴づける外周部の black ring と乳白色部について EMX による分析を試 みた。使用した試料は正常・異常放電を示すもの各 1 試 料で，鏡面研摩した分析面に放電痕を生成させた.この 実験は $\mathrm{Ag}$ (刘電極材料) と C (試料以外のソースとし てアルゴン中に微量含まれる炭化水素が考えられる）に ついて行なつたが，これらの元素は未放電部分と放電痕 外周部で顕著な差を示さなかつた。Cに関しては確認の ため純アルミニウム試料面に得た black ring について も調査したが，同様の結果を得た。

この実験から，正常放電の場合には放電が中心部に限 定され，試料蒸気が放電力ラムの周辺部で冷却され試料 面に付着して black ring を形成するものと推定され る、いつぽう異常放電では放電特性に变化を生じ, 放電 チャネルの分散した拡散放電となるため放電痕の外周部 においても放電が行なわれるので，生成した試料微粒子 はアルゴンによつて運び去られ, black ring の生成が妨 げられて乳白色吕する。この乳白色部分に関しては BROWN ら ${ }^{10)}$ が放電痕が白色を呈するのは放電によつて 生じた非常に多数のきわめて微細なタレーターの存在に よると報告している。

以上に述べた放電痕についての実験および考察から， カントバック分析において経験的に行なわれている放電 痕の観察による正常, 異放電の判定はじゅうぶんな根 拠をもつものと判断される。しふしながら，実際の分析 で推察される放電痕はここで述べたように判然としたも のばかりではなく，むしろ両者の中間に分類されるもの が多い，したがつて，正裳，異常放電の判定基準として は，より客観的と考えられる積分時間の監視に重点を置 
くベきであろう.

$3 \cdot 1.5$ 電極間の励起原子の分布

電極間げきにおける各元素の励起原子の分布が熄一で ないことは，電極構成あるいは $\mathrm{SN}$ 比の向上などの理由 で電極間げきの中心が光軸の上部に設定されている点な どによつてじゅうぶえ子測されるが, 正常, 異常放電に おいてどのような現象上の差異を示すかについて検討を 行なつた.

本実験では，電極間げきを一定 $(6 \cdot 0 \mathrm{~mm})$ とし Fig. 1 に示した規定の設定位置を中心として, 上方へ $1.0 \mathrm{~mm}$, 下方へ $2.5 \mathrm{~mm}$ 電極支持台を移動し, 定強度積分法によ り $\mathrm{Si}, \mathrm{Mn}, \mathrm{P}, \mathrm{S}$ のスペクトル線強度の変化を調べた.

Fig. 2 に各位置における正常, 異常放電時の積分時間 の変化を示したが，これは内標準線 Fe II 2714·4 の強 度变化と対応している. 寸なわち積分時間の短い位置で はその強度が高く, 逆に長い位置では低いことを示して いる. 同図は正常放電試料 2 個（試料番号 1，2）, 異常 放電試料 3 個 (3，4，5) についての測定結果であるが,

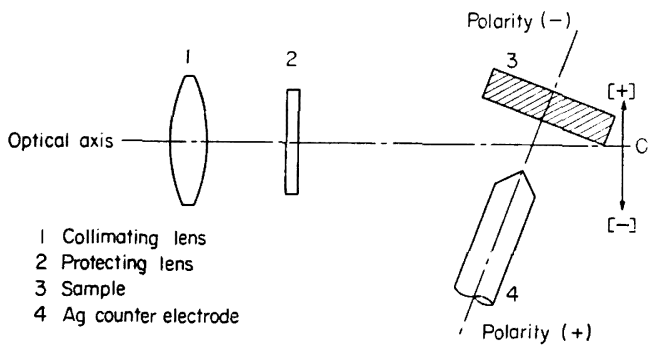

Fig. 1. Relation between optical axis and position of electrodes.

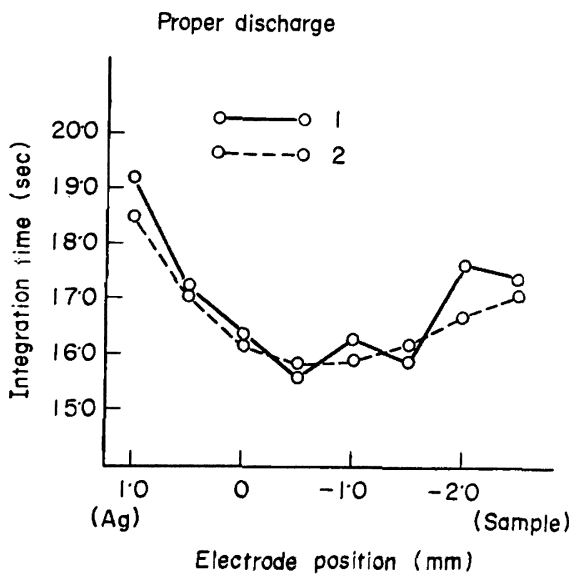

正常放電の場合，比較的スムーズな分布曲線が得られた のに対し, 異常放電では試料および位置によつて強度が 著しく変動している.

正常放電について励起原子の分布の傾向をみると, 密 度の最大は電極間げきの中心付近にあるが，対称的では なく対電極に比較し試料側の密度が高い. 異常放電の場 合にもややその傾向が認められるが，試料によつては対 電極側の 密度が 極端に 低く検出されるものがあつた.

$\mathrm{Si}, \mathrm{Mn}, \mathrm{P}, \mathrm{S}$ のスペクトル線強度の分布を Fig. 3〜6 に示した.

図から明らかなように，この分布は元素により特徵的 である. 正常放電の場合, $\mathrm{Si}$ は 0 の位置, すなわち規 定の電極設定位置付近に密度の高い部分があるが，P， $\mathrm{S}$ ではその位置が $1 \mathrm{~mm}$ 程度試料側に寄つたところにあ る. Mn の場合は対電極付近の密度がもつとも高く, 試 料側に近づく注ど低くなる傾向をもち，他の元素とはま つたく異なつた挙動を示した。

異常放電でもほほ同様の傾向が認められたが，積分時 間の場合と同じく, 試料間での変動が大であつた.

これらの実験結果から放電の異常性と励起原子の分布 状態の差との関係を完全に説明することは困難であるが 少なくともブレークダウン後の放電チャネルの収縮過程 において電流密度, 試料の蒸発量を低下させるような特 異な現象が 発生していることはじゅうぶんに推察され る.

\section{2 異常放電が分析値へあたえる影響}

\section{$3 \cdot 2 \cdot 1$ 蒸発·励起曲線}

異常放電を起こした場合，積分時間，分析値に異常が

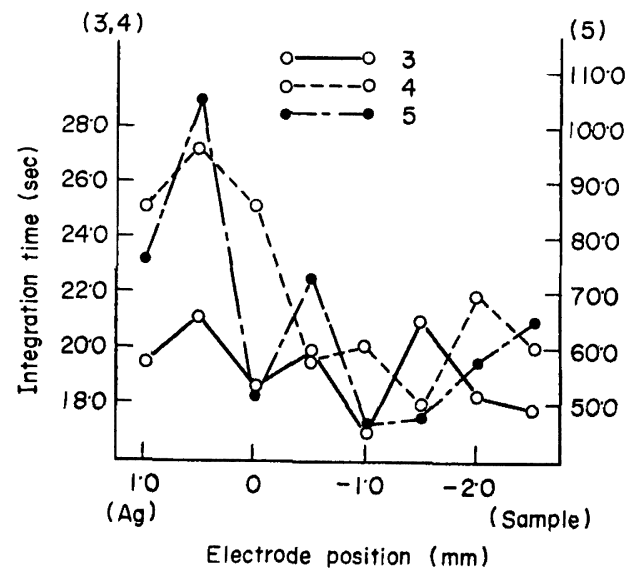

Fig. 2. Effects of vertical position of electrodes on integration time. 
Element : Si

Proper discharge

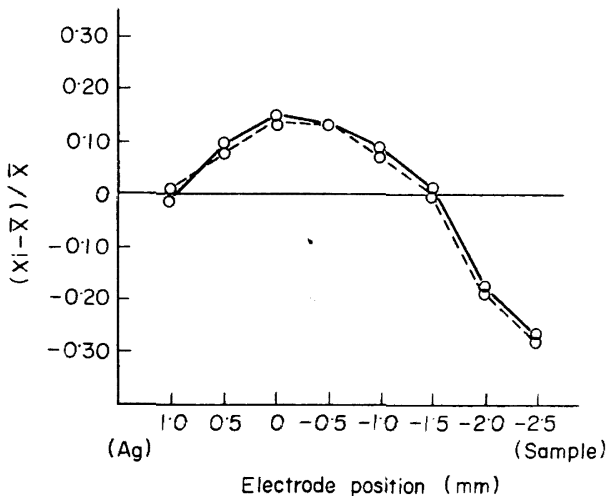

$X_{i}$ : Chart reading

Improper discharge

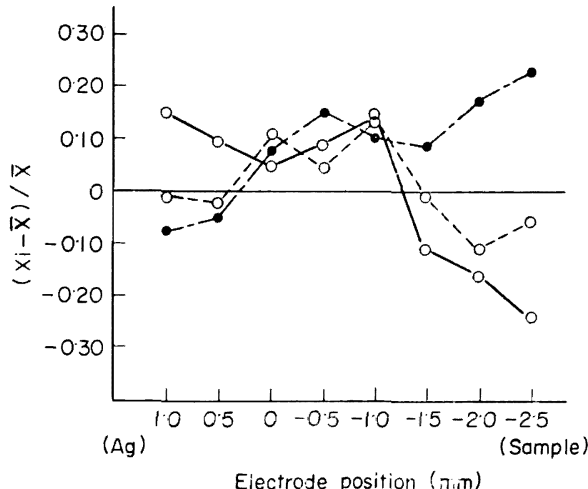

Fig. 3. Distribution of excited atoms between electrodes.

Element : $\mathrm{Mn}$
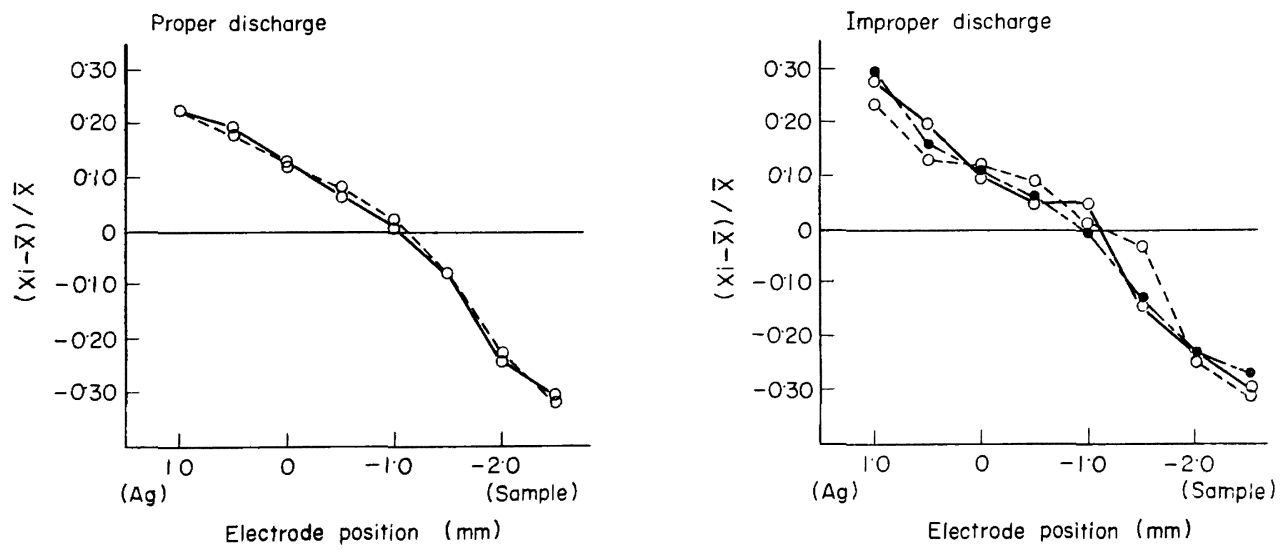

Fig. 4. Distribution of excited atoms between electrodes.

認められることはすでに述べたが，ここでは内標準線よ 分析線の蒸発・励起曲線を調べることによつて, 正常, 異常放電の特性を比較検討した．この結果を Fig. 7〜9 に示す.

正常放電では比較的スムーズな曲線が得られ，特異な 傾向を示す $\mathrm{S}$ を除き，スペクトル線強度の立ちあがりが 急で, 数秒以内にピークに達しそのまま安定に推移して いる. これに対して異常放電における強度の上昇はゆる やかで，実験を行なつた 60 秒間では正常放電のレベル には到達せず，起伏も大きく放電の不安定さを示してい る.

異常放電における積分時間の延長は，Fig. 7 の予備放
電時間 $(10 \mathrm{sec})$ に相当する部分を除いた積分強度を正 常放電のそれと比較することによつて, 容易に理解する ことができる.

同様に，分析線対間の積分強度を比較することにより 異常放電時に Si，P の分析值が低值を示すことが予想さ れる.

以上のように使用スペクトル線の蒸発・励起曲線が放 電間で著しく異なる場合には，もはや元素の含有率と線 対強度比のあいだに一定の関係が成り立たなくなり, 同 一の検量線で分析を行なうときには，無視することのて きない誤差を伴うことになる. 

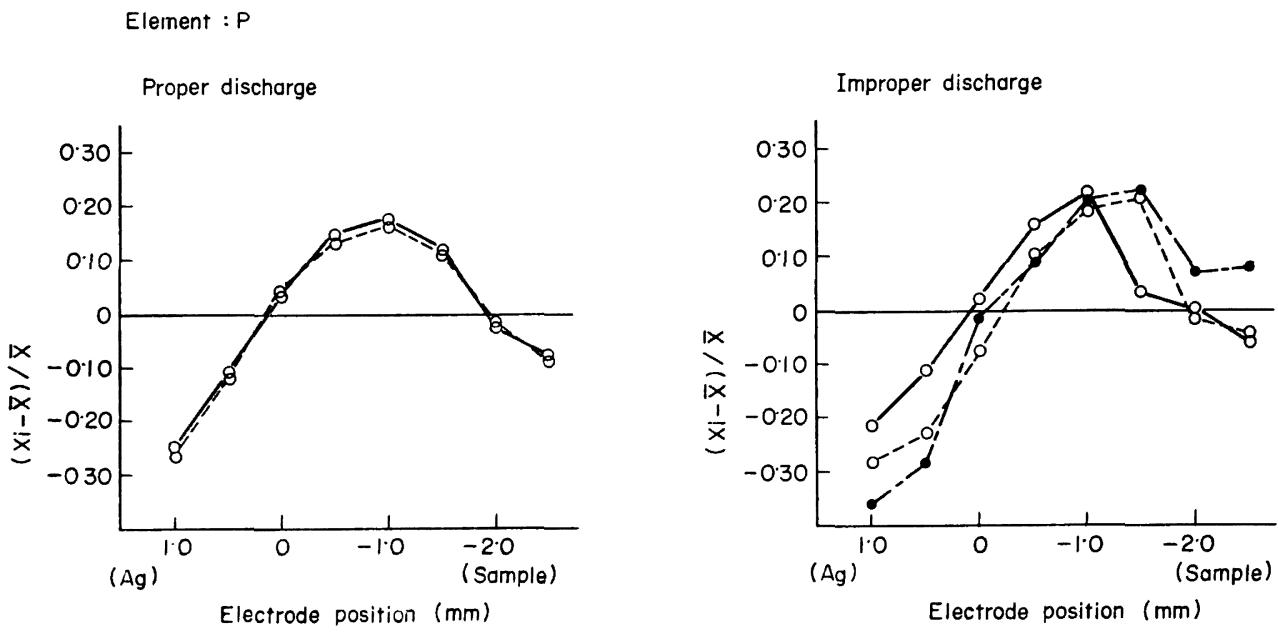

Fig. 5. Distribution of excited atoms between electrodes.
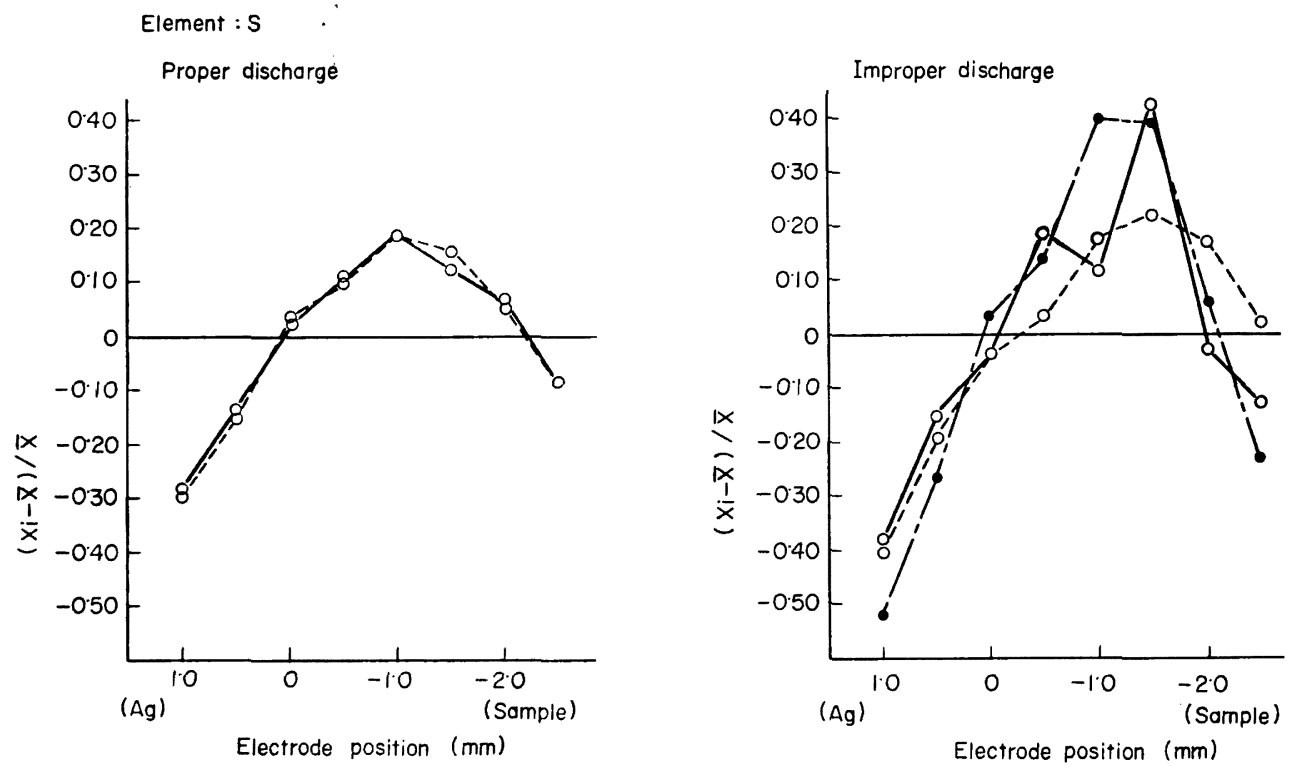

Fig. 6. Distribution of excited atoms between electrodes.

\section{$3 \cdot 2 \cdot 2$ 分析值への影響}

正常，異常放電は $3 \cdot 1 \cdot 4$ で述べたように放電痕によ り，明確に区別することはむずかしく，放電の異常性に 起因する分析結果への影響は連続的である.

そこで放電の異常性と分析誤差の関係，分析許容差を 考虑したときの判定基準などの問題について検討するこ とにした．ここで放電の異常性を判断する因子としては 定強度積分法における積分時間を特性值とした.
日常分析試料から 60 試料を選択し， $\mathrm{n}=2$ の分析を 行なつた.これらの試料には正常, 異常放電試料がほほ 同数含まれるように配慮した.

Fig. 10 には積分時間のヒストグラムを，また Fig.11 には積分時間が $16 \cdot 8 \sim 18 \cdot 9 \mathrm{sec}$ の間にある 81 放電に ついてのヒストグラムを示した.なおこの分析において は正常な分析試料で $17 \mathrm{sec}$ 程度の積分時間になるよう に調整した. 
Fe II $2714.4 \AA$

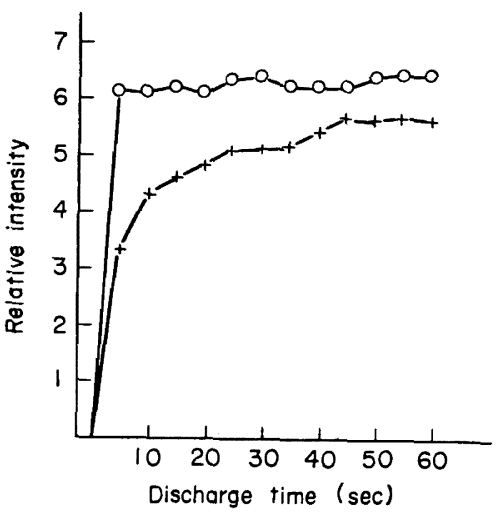

Fig. 7. Volatilization curves.

Mn II $2933 \cdot 1 \AA$

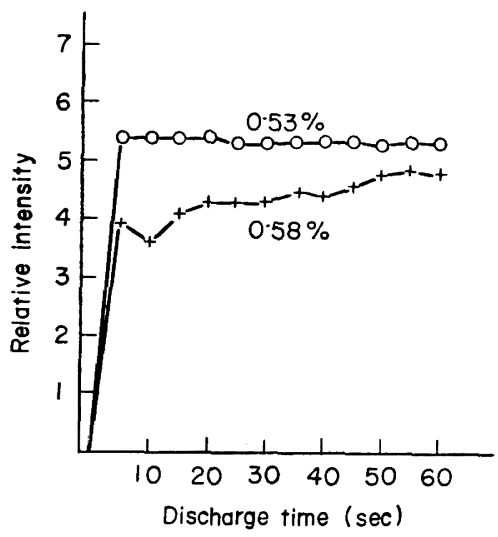

Fig. 11 にみるようにその時間帯で積分を完了する試 料の頻度は高く，これらは正常試料として分類される試 料であるが， $36 \mathrm{sec}$ 程度の積分時間を要する試料も認め られた。この積分時間の变動が分析結果にあたえる影響 を調べるため，上記結果のうち積分時間が $19 \mathrm{sec}$ 以上の 試料を選び標準分析值に対する差と積分時間の関係につ いて検討した.

この結果は Fig. 12〜13 に示す.

Sを除き積分時間が長くなるほど分析值は低值を示

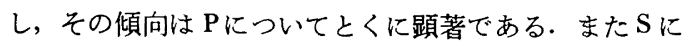
いては $20 \mathrm{sec}$ 付近でその差は極端な高值を示し，積分 時間が長くなるほどその差は小さくなる傾向を示してい る. いずれの元素も $20 \mathrm{sec}$ 付近を基準に考えると，積分 時間が長くなるほど低值をあたえる傾向のあることがわ

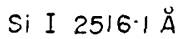

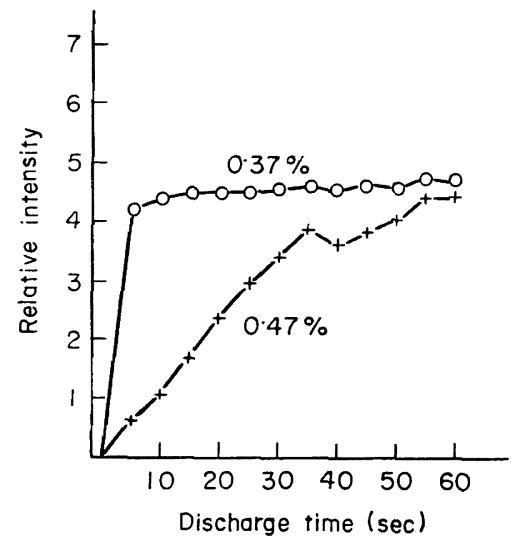

Fig. 8. Volatilization curves.

PI $1782 \cdot 9 \AA$

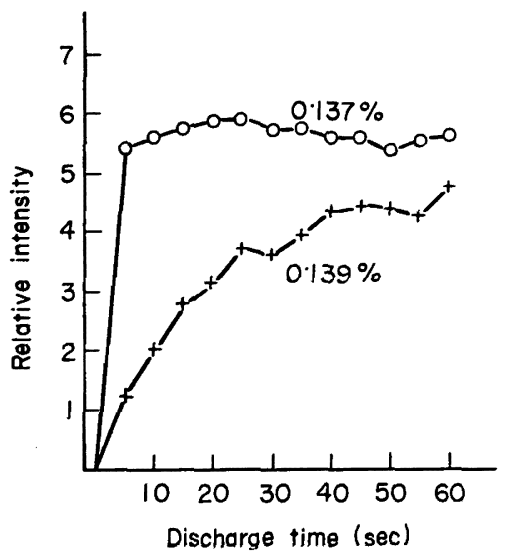

SI $1807 \cdot 3 \AA$

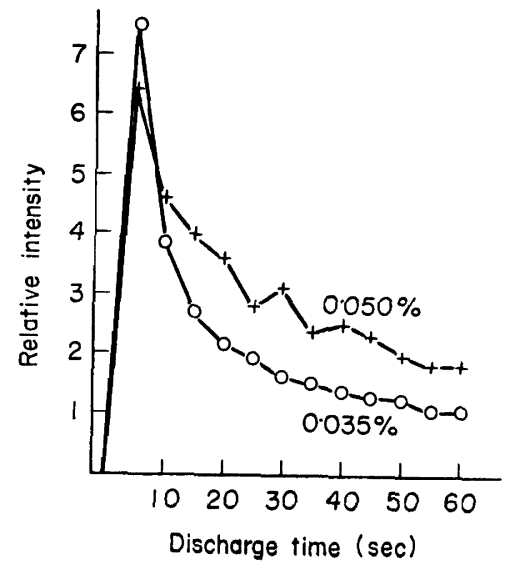

Fig. 9. Volatilization curves. 


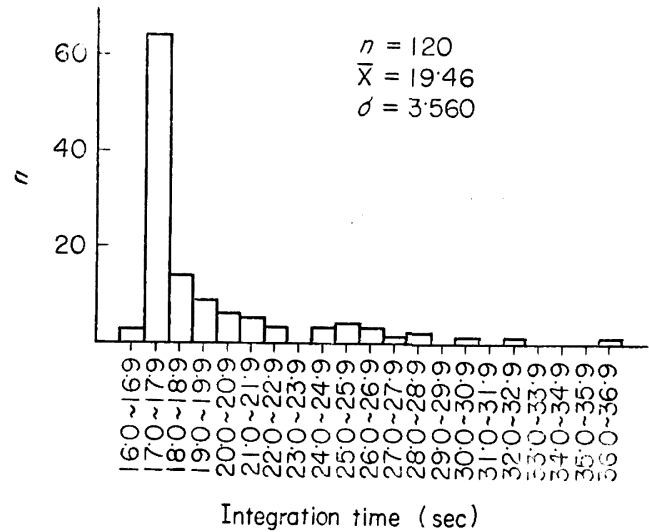

Fig. 10. Distribution of integration time.

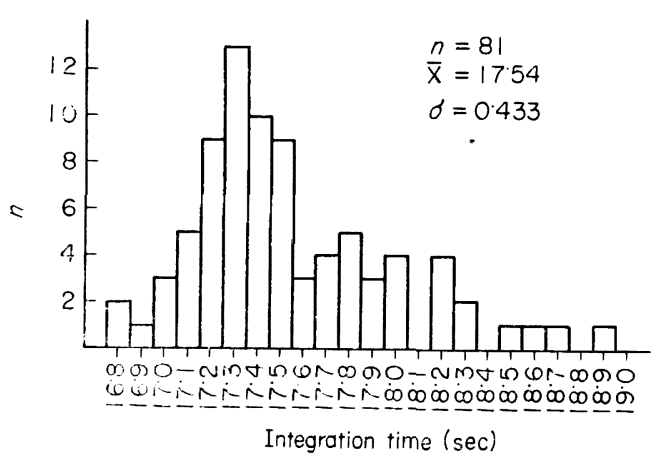

Fig. 11. Distribution of integration time $(16 \cdot 0 \sim 19 \cdot 0)$

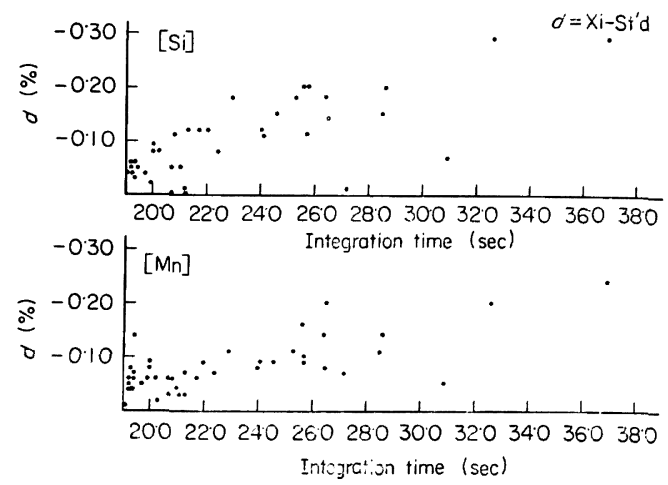

Fig. 12. Relation between integration time and difference in analytical values.

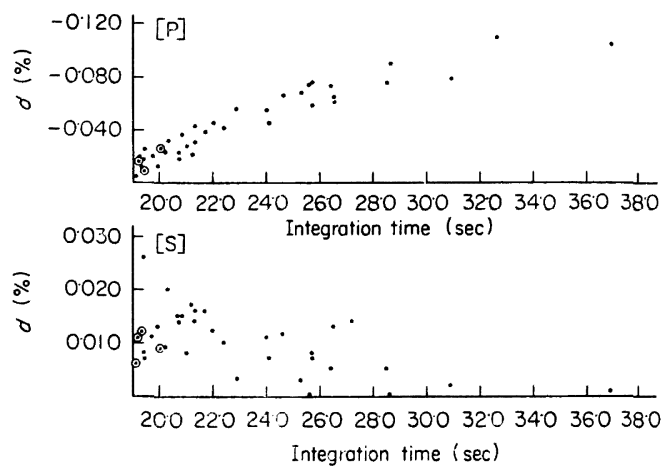

Fig. 13. Relation between integration time and difference in analytical values.

Table 2. Reproducibility.

\begin{tabular}{|c|c|c|c|c|c|c|c|c|c|c|}
\hline \multirow{2}{*}{ No } & \multicolumn{5}{|c|}{ Proper sample } & \multicolumn{5}{|c|}{ Impropr sample } \\
\hline & $\begin{array}{l}\text { Int. } \\
\text { Time }\end{array}$ & $\underset{(\%)}{\mathrm{Si}}$ & $\begin{array}{l}\mathrm{Mn} \\
(\%)\end{array}$ & $\underset{(\%)}{P}$ & $\underset{(\%)}{\mathrm{S}}$ & $\begin{array}{l}\text { Int. } \\
\text { Time }\end{array}$ & $\underset{(\%)}{\mathrm{Si}}$ & $\underset{(\%)}{\mathrm{Mn}}$ & $\underset{(\%)}{\mathbf{P}}$ & $\underset{(\%)}{\mathrm{S}}$ \\
\hline 1 & $16 \cdot 9$ & $0 \cdot 44$ & 0.55 & $0 \cdot 151$ & 0.045 & $28 \cdot 9$ & $0 \cdot 21$ & 0.51 & $0 \cdot 066$ & 0.049 \\
\hline 2 & $17 \cdot 9$ & 0.44 & 0.55 & $0 \cdot 147$ & $0 \cdot 045$ & $27 \cdot 3$ & $0 \cdot 20$ & $0 \cdot 46$ & $0 \cdot 063$ & 0.042 \\
\hline 3 & $18 \cdot 2$ & 0.45 & 0.58 & $0 \cdot 148$ & $0 \cdot 043$ & $31 \cdot 2$ & 0.15 & $0 \cdot 43$ & 0.047 & 0.041 \\
\hline 4 & $18 \cdot 3$ & 0.45 & 0.59 & $0 \cdot 148$ & 0.043 & $30 \cdot 5$ & $0 \cdot 16$ & $0 \cdot 44$ & $0 \cdot 050$ & 0.049 \\
\hline 5 & $17 \cdot 8$ & 0.44 & $0 \cdot 56$ & $0 \cdot 145$ & 0.044 & $29 \cdot 1$ & $0 \cdot 19$ & 0.47 & 0.059 & 0.040 \\
\hline 6 & $17 \cdot 6$ & $0 \cdot 45$ & 0.56 & $0 \cdot 147$ & 0.045 & $27 \cdot 5$ & $0 \cdot 22$ & 0.49 & 0.069 & 0.043 \\
\hline 7 & $17 \cdot 9$ & 0.45 & 0.57 & $0 \cdot 148$ & 0.045 & $33 \cdot 3$ & $0 \cdot 17$ & $0 \cdot 44$ & 0.047 & 0.043 \\
\hline 8 & $18 \cdot 3$ & 0.42 & 0.55 & $0 \cdot 140$ & 0.043 & $29 \cdot 7$ & $0 \cdot 16$ & 0.44 & 0.053 & 0.040 \\
\hline 9 & $18 \cdot 2$ & 0.45 & 0.56 & $0 \cdot 146$ & 0.047 & $27 \cdot 9$ & $0 \cdot 18$ & 0.45 & 0.063 & 0.040 \\
\hline 10 & $18 \cdot 3$ & 0.45 & 0.56 & $0 \cdot 146$ & $0 \cdot 044$ & $31 \cdot 6$ & $0 \cdot 14$ & 0.42 & 0.046 & 0.041 \\
\hline $\bar{X}$ & $17 \cdot 85$ & 0.445 & 0.563 & $0 \cdot 1463$ & $0 \cdot 0444$ & $29 \cdot 70$ & $0 \cdot 178$ & 0.455 & 0.0563 & 0.0418 \\
\hline$\delta$ & 0.53 & 0.011 & $0 \cdot 13$ & $0 \cdot 0028$ & $0 \cdot 0010$ & $1 \cdot 85$ & 0.025 & 0.026 & 0.0082 & 0.0026 \\
\hline
\end{tabular}

かる.

そこでこの関係についてさらに確認を行なうため正常 . 異常放電試料を各 1 試料選び, くり返し $(\mathrm{n}=10)$ 分 析を行なつた。
その結果を Table 2, Fig. 14, 15 に示す.

異常放電試料は積分時間および分析值の標準偏差が 2 〜3 倍となる.なお Fig. 14，15 は各試料についてその 平均積分時間，平均分析值に対するそれぞれの差の関係 


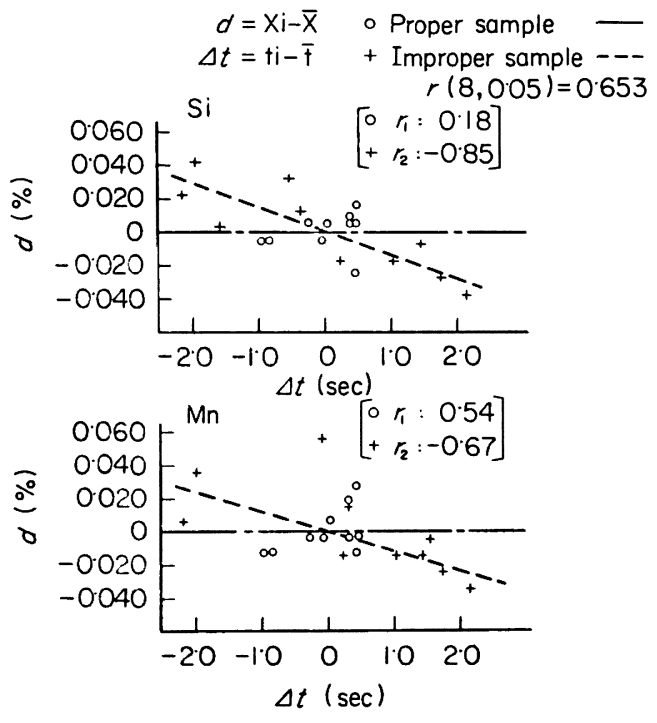

Fig. 14. Relation between integration time and analytical values.
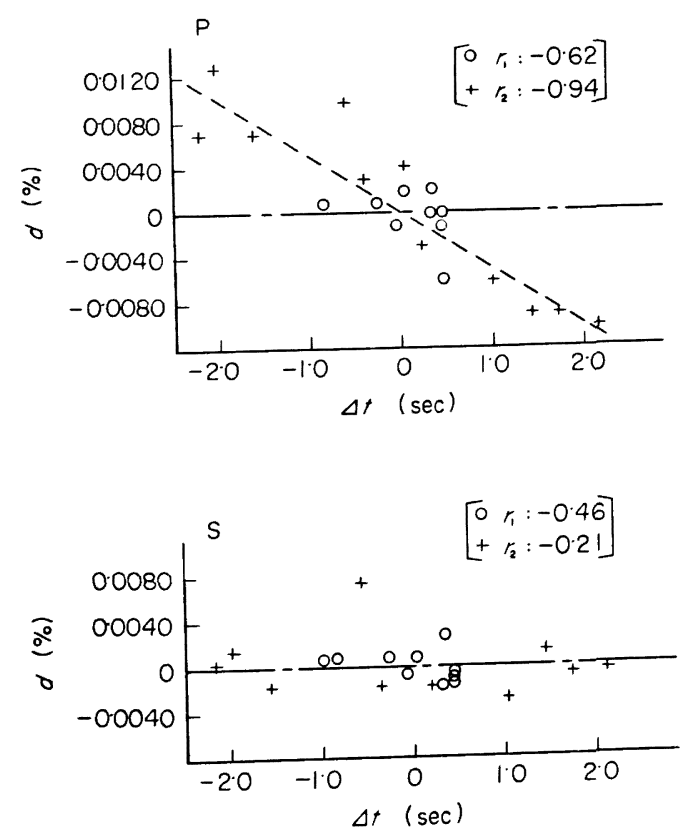

Fig. 15. Relation between integration time and analytical values.

について示したものであるが，異常放電の場合の分析値 は積分時間が規定值 $(17 \mathrm{sec})$ より長くなつたことに相 当する量の偏差を含んでいることを考虑しておかねばな らない. 相関係数 $(r)$ からも明らかなように異常放電
の場合, Sを除く元素については Fig. 12，13 と同様に 積分時間が長くなるほど分析值は低值をあたえる傾向を 示し，その傾向は $\mathrm{P}$ についてとくに顕著である. また $\mathrm{P}$ については正常な試料についてもややその傾向が認めら れる。

しかしSについてはその傾向を認めず，正常放電に比 較し, 異常放電のときの精度が低下することのみを認め た.

この実験結果から推定すると内標準元素の励起に比較 し分析元素の励起は抑制された状態にあり，その抑制度 合は単位時間における内標準元素である Fe の励起量と 関数関係にあることがわかる.

そこで，放電の異常性に起因する䛊差を除く一つの方 法として積分時間により放電の異常性を判断し, 異常放 電による分析值を積極的に除外する方法が考えられる.

分析值の变動に対する積分時間の影響についてつぎの ような検討を行なつた。

積分時間が増加する現象と異常放電とを関連づけるに は，人為的に異常放電を起こさせ，増加する積分時間を 定量的に把握することが必要となる．すでに述べたよう に異常放電がグラファイトの析出と密接な関連があるの で正常放電試料の表面を削りとつていくことにより連続 的に異常放電へ移行させうることは容易に考えられる. 実験の信頼性を増すため 4 試料を選び，放電と研摩をく り返しながら積分時間の増加と強度を調べた。試料によ り異なるが異常放電現象を起こすには 10〜120回の分析 が必要であり，これは研摩深さ $0.4 〜 7.0 \mathrm{~mm}$ に対応し た.

その結果, 積分時間と平均分析值に対する差の関係を 元素別にみると, $\mathrm{S}$ を除き積分時間の増大とともに差は 大きく低值を示しかつその傾向はよく一致していた.

このことは分析值の变動に対する積分時間の影響は高 度に有意であり，その関倸は元素により一定であること を示している.

Fig. 16 には 4 試料の平均的な傾向を示した. この実

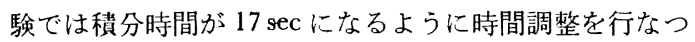
たので, 平均積分時間である $17 \mathrm{sec}$ 付近でその差は 0 を 示している.

しかし Sについては他の元素ほど明確な関係を認める ことはできなかつた.

Fig. 16 に示した関係から積分時間の変動による分析 值への影響度は

$$
\begin{aligned}
& \mathrm{Si}: 0.021 \% / \mathrm{sec} \\
& \mathrm{Mn}: 0.013 \% / \mathrm{sec} \\
& \mathrm{P}: 0.0099 \% / \mathrm{sec}
\end{aligned}
$$




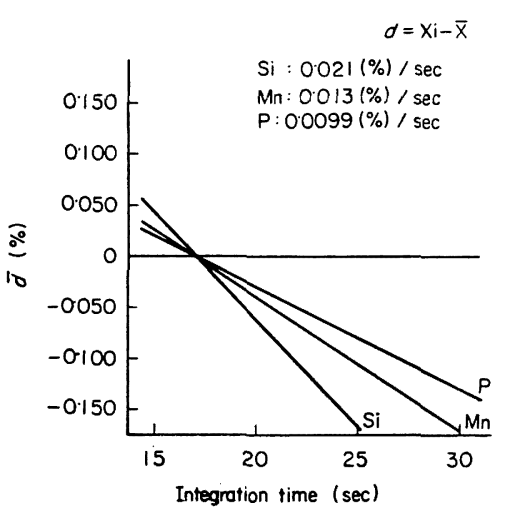

Fig. 16. Relation between integration time and difference in analytical values.

で，積分時間が長くなればいずれの元素も低值をあたえ ることになる．これを積分時間の変動による系統的誤差 として考虑すると積分時間が規定值に対し $1 \mathrm{sec}$ 以上の 差をもつ場合，その分析值は慎重にとり扱わなければな らないことになる.

この積分時間範囲と分析精度, 平均分析值の変化につ いては Fig. 17 に示した.

平均分析值について顕著な变化を示す元素は $\mathrm{Si}, \mathrm{P}$ で あり Mn もその傾向を認める。 また分析精度について は同様に $\mathrm{Si}, \mathrm{Mn}, \mathrm{P}$ が影響を受け，とくに積分時間が $20 \mathrm{sec}$ を過ぎると精度に対する積分時間の影響は無視で きない，そこでこの影響を分析值の正確さの観点からみ ると Table 3 のようになる.

$\mathrm{Si}, \mathrm{Mn}, \mathrm{P}$ についてはいずれも $0.05 \sim 0 \cdot 10 \%$ の低 值を示すと同時にそのバラッキは大きくなる.

ここでは積分時間を $20 \cdot 1 \mathrm{sec}$ 以上とそれ以下に区別

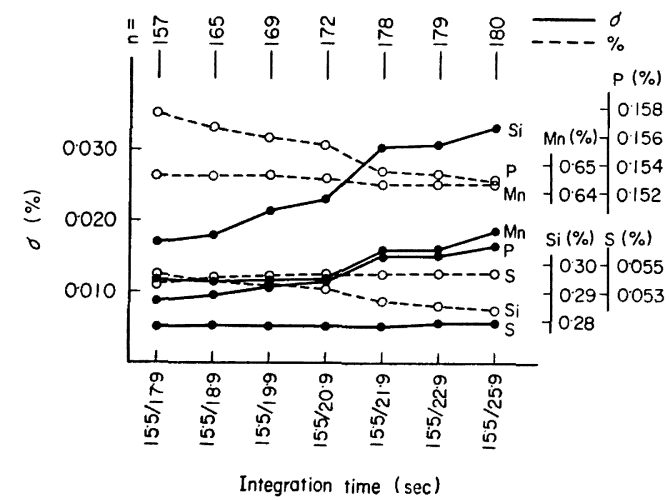

Fig. 17. Relation between range of integration time and mean values or analytical precision.
Table 3. Effect of integration time on analytical values.

\begin{tabular}{|c|c|c|c|c|c|}
\hline Int. time & \multicolumn{2}{|c|}{$\begin{array}{c}15 \cdot 5 \sim 20 \cdot 0 \\
\sec \end{array}$} & \multicolumn{2}{|c|}{$\underset{\sec }{20 \cdot 1 \sim 25 \cdot 9}$} & \multirow{2}{*}{$\begin{array}{l}\Delta \bar{X} \\
(\%)\end{array}$} \\
\hline $\bar{X}, \sigma$ & $\begin{array}{c}\bar{X} \\
(\%)\end{array}$ & $\begin{array}{c}\sigma \\
(\%)\end{array}$ & $\begin{array}{c}\bar{X} \\
(\%)\end{array}$ & $\left(\begin{array}{c}\sigma \\
\%\end{array}\right)$ & \\
\hline $\begin{array}{l}\mathrm{Si} \\
\mathrm{Mn} \\
\mathbf{P} \\
\mathrm{S}\end{array}$ & $\mid \begin{array}{l}0 \cdot 292 \\
0 \cdot 646 \\
0 \cdot 1559 \\
0 \cdot 0541\end{array}$ & $\begin{array}{l}0 \cdot 021 \\
0.012 \\
0 \cdot 0106\end{array}$ & $\begin{array}{c}0 \cdot 189 \\
0.595 \\
0 \cdot 1053 \\
0 \cdot 0586\end{array}$ & $\begin{array}{l}0 \cdot 034 \\
0 \cdot 030 \\
0 \cdot 0161 \\
0 \cdot 0052\end{array}$ & \\
\hline
\end{tabular}

し分析精度，正確さの推定を行なつた。これより積分時 間範囲は小さくとることが望ましい，し沫しこの点につ いては溶銑分析における許容呮差を考慮し决定する必要 があろう。

\section{3 異常放電に対する分析条件の検討}

\section{$3 \cdot 3 \cdot 1$ 異常放電に対する内標準線の影響}

カントバック分析の積分過程において，積分時間を規 制する方法に，定強度積分法之定時間積分法がある.

一般には定強度積分法が採用されているが，この方法 は基準元素 (内標準元素) の特定スペクトル線の積分強 度が一定値になるまで積分を行なう方法である。

また定時間積分法は一定時間の積分を行ない，検出さ れた各元素と基準元素の強度比から検量を行なう方法で あるが，この場合基準元素の含有率範囲が広くなければ 各元素の強度で検量できる特長をもつている．しかし実 用上は特殊な場合を除き，強度で検量を行なうことはな い、いずれにしても検量段階では強度比を用いることに なるのであるが，この内標準線としては鉄鋼材料の分析

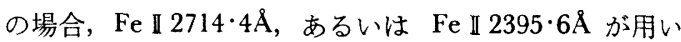
られる.これらはいずれもイオン線で，その励起電圧は $14 \mathrm{eV}$ 程度であり, 中性原子線を分析線とする場合, 励 起電圧の差 $(\Delta \mathrm{E})$ は 7〜9eV になる. このように分析 線と内標準線の励起電压の差が大きい場合は励起温度な よ゙，励起条件のわずかな変動が強度比に大きく影響をあ たえることが予測される.

そこで異常放電における積分時間の延びについて，こ れを単純に解釈すると $\mathrm{Fe}$ 原子の励起過程においてなん らかの抑制効果が存在したものと考えるべきである.

しかしその過程において励起の選択性がなく，また内 標準線が励起の異常性を完全に監視できるならば，それ らが分析結果にあたえる影響はほとんど無視できる程度 のものであろう。

この定強度積分法に㧍ける内標準線の問題について, つぎのような実験を行なつた。

内標準線としては $\mathrm{FeI} 2714.4 \AA$ のほかに 0 次の光, 


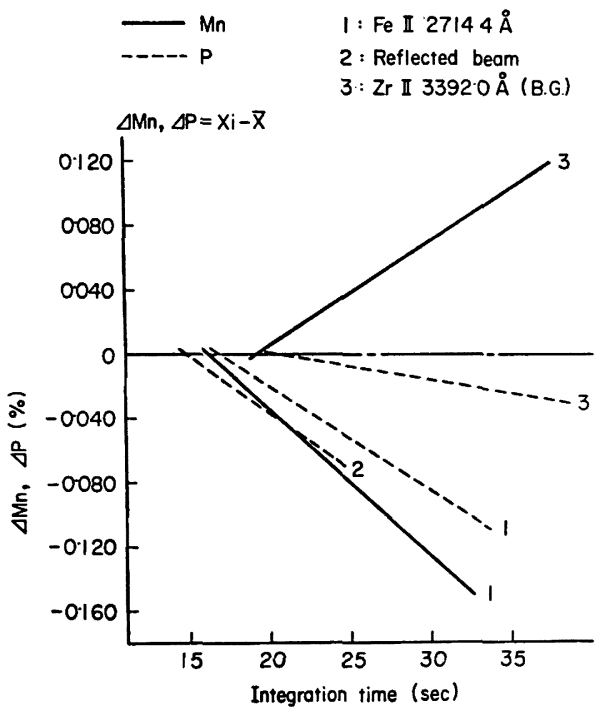

Fig. 18. Effects of various internal lines on analytical values.

すなわち reflected bean (非回折光) と試料中の含有率 が無視できるであろうと考える $\mathrm{Zr} \mathbb{1} 3392 \cdot 0 \AA$ (バックグ ラウンド）の強度を用いることにした。

上記 3 種類のスペクトル線強度を内標準とし, 異常放 電を起こす試料について分析を行なつた，その結果を Fig. 18 に示す. これは積分時間と各分析値の標準分析 值からの差について示したものである.

Fe 内標準のときは $\mathrm{Mn} ， \mathrm{P}$ ともに積分時間が延びる にしがたい分析值は低值をあたえる傾向を示すが， Zr I

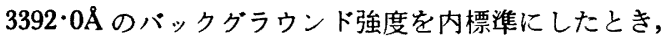
Mn は逆の傾向を示す. また Pの傾向は $\mathrm{Fe}$ 内標準のと きと同様であるが，その影響度は 1/3 以下である。

つきに reflected beam を内標準とするときはPのみ 低値を示す傾向を認め，Mnについてはそのような傾向 を認めなかつた。

ここで放電のプラズマ采に熱平衡が成立するものと仮 定するならば，スペクトル線強度（I）はつぎのように 定義することができる.

$$
\begin{aligned}
& I=\nu A_{\nu} N h_{\mathrm{exp}}(-E / k T) \\
& \text { ע：振動数 } \\
& A_{\nu} \text { : 透移確率と統計的重価の積 } \\
& N \text { : 原子数 } \\
& h: \text { プランクの定数 } \\
& E \text { : 励起電圧 } \\
& k: \text { ボルツマンの定数 } \\
& T: \text { 励起温度 }
\end{aligned}
$$

ここで強度比について考えてみると， $\log \left(I_{1} / I_{2}\right)=\log A \cdot\left(N_{1} / N_{2}\right)-(\Delta E / k T) \log e$

$$
\left[\begin{array}{l}
A=\nu_{1} A_{\nu_{1}} / \nu_{2} A_{\nu_{2}} \\
\Delta E=E_{1}-E_{2}
\end{array}\right]
$$

となり, 励起温度が異常放電等により变化したとき, 強 度比 $\left(I_{1} / I_{2}\right)$ はプラズマ中の原子濃度比 $\left(N_{1} / N_{2}\right)$ のほ かに $\Delta E$ の関数になつていることがわかる.

そのような場合 $|\Delta E| \gg 0$ であれば第 2 項の寄与する 割合は高くなる。 そして $\Delta E>0$ と $\Delta E<0$ で $I_{1} / I_{2}$ に

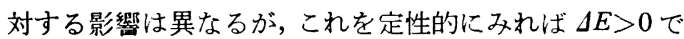
は強度比に対し負の影響を，また逆に $\Delta E<0$ のときは 正の影響を示すことになる.

この実験で用いた内標準線については Fe II 2714・1 以外の励起電圧を知ることはできなかつたが，本実験に おける異常放電が励起電圧の差に起因するものが支配的 であると仮定するならば，その励起電圧はおよそつぎの ように推定することができる.

$$
E_{\mathrm{FeII}}>E_{\mathrm{MnII}}=E_{\mathrm{R} . \mathrm{B} .}>E_{\mathrm{ZrII}(\mathrm{B} . \mathrm{G} .)}>E_{\mathrm{PII}}
$$

内標準線に $\mathrm{Fe}$ の中性原子線を用いて実験すれば，この 第 2 項の影響を確認することができると考えられる。し かし現状の装置上の制約からこれを確認することはでき なかつた。

現在，一般に採用されている内標準線法の再検討と， そのスペクトル線の選定基準を明確にすることは今後に 残された一つの重要な課題である.

\section{$3 \cdot 3 \cdot 2$ 分析值におよぼす予備放電時間の影響}

予備放電の効果については Fig. 7 9 に示したように 時間経過とともにその強度は高くなるという結果を得て いる.したがつてその強度变化の傾向から推察すると時 間経過とともに異常放電から正常放電人移行する傾向が 認められる. そこで内標準線を Fe II 2714.4A と ZrII $3392 \cdot 0 \AA$ (バックグラウンド) の強度とし，予備放電時 間 $10 \mathrm{sec}, 30 \mathrm{sec}, 60 \mathrm{sec}$ についてその影響を調べた。 結果を Fig. 19 に示す. この場合異常放電の程度は各子 備放電時間に打ける分析值の標準分析値からの差とその バラッキで評価した，Fig. 19 によれば，Sについては 内標準線の種類，予備放電時間の影響を認めない. $\bar{d}$, $\sigma$ ともに大きな変化を示さず，またとの平均的な值も無 視できる程度のものである.

$\mathrm{Si}$ の場合 $\mathrm{Fe} \mathbb{I}$ 2714.4A を内標準とするときは予備放 電時間を長くとるほどずは小さなり， $\sigma$ も同様の傾向 を示し，予備放電時間を 長くとることの効果を認める が，Zr I I392.0』 については必ずしもその効果は認め られない.しかし可のみについては予備放電時間 $10 \mathrm{sec}$ ですでに低值をとつている. 


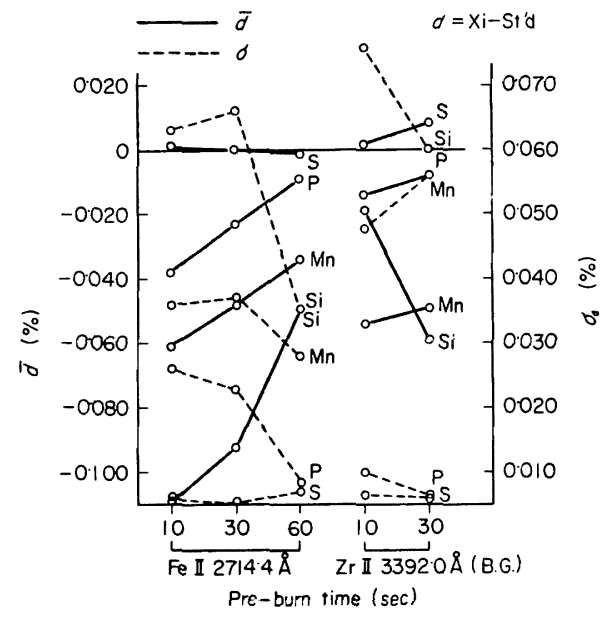

Fig. 19. Relation between pre-burn time and analytical values or analytical precision.

$\mathrm{Mn}$ もほぼ $\mathrm{Si}$ に類似した傾向を示し，とくに $\sigma$ につ いては顕著にその効果を認める.

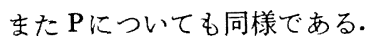

この結果から内標準線の選定法, あるいは予備放電時 間を長くとることの問題について結論することは困難で あるが，放電初期におけるストリーマーが試料面に存在 するグラファイト周辺に集中することから考えれば，そ れらの放電点が破壊された時期に積分を開始すれば，異 常放電における選択放電の問題は比較的低い準位でしか 寄与せず，その影響度が低位であるためと考えられる.

\section{4. 考察}

鉄鉄の異常放電は実用分析に才いては必要とする分析 值が得られないという直接的損失を伴うので重大な問題 であるとともに，発光分光分析における放電現象からみ ても興味深い問題を含んでいる. 試料の凝固過程で生じ るピンホールやクラックが異常放電を起こさせることは 容易に理解でき，実用面では事前に処置しうるが，本実 験では分析操作ののちはじめて明らかとなる異常放電が グラファイトの析出に関連していることを明らかにし た. 異常放電の現象の確認には放電痕の観察および積分 時間が指賩になることを指摘し，この両者について詳細 な観察を行なつた。しかしグラファイトの析出は連続的 に推移する現象であることから digital な情報を要求す る分析值と定量的に絬び付けることはきわめて大きな困 難を伴う。したがつて本実験において正常, 異常の境界 がグラファイト存在量 $0.5 \%$ であると指摘できたとはい え, $0.5 \%$ 以下の試料においても正常, 異常放電の中間
的な放電をしているおそれがあるのでそれを明確にでき ないということから，得られた分析值には，異常放電に もとづく不正確さがある程度含まれていることを予测し ておかねばならない。

したがつてこれらの問題が相乘的に寄与・影響し，銑 鉄分析の精度，正確さを低下さす原因になつているもの と判断される. これに処する直接的な対策として一般に 採られるのが鋳型の構造, チル化促進剤の添加などの検 討により，グラフォイトの析出を阻止する手段である ぶ，銑鉄試料の炭素量は 4.3〜 4.6\% であることを考虑 すれば，これらを完全に白銑化組織として採取すること は困難である．それゆえ異常放電の発生機構の解明によ り，新しい試料調製法あるいはは励起法を演繹しようと する試みがなされるわけである.この目的の下に行なわ れた本研究においては, 確定的な結論は得られなかつた が，放電の初期にグラファイト周辺部に放電点が集中す るということから，パーライト，炭化物あるいは非金属 介在物などの存在による優先放電あるいは選択放電で説 明される現象之同様に不安定な放電となり，放電カラム のプラズマが試料組成を代表しなくなる現象であること は少くとも肯定されるといえよう.

本研究の範囲内では本質的解決策を与えることはでき ないとしても，実用的には放電点破壊が完了するまでの 期間を予備放電として除外する方法が考えられ，そして その効果は認めることができた. しかしその所要時間は 30〜 60 sec あるいはそれ以上を必要とする試料もあつ た。

子備放電の延長により異常放電を回避することは日常 分析において分析所要時間を長くするという実用上の障 害を伴ら久点がある.

このような実験経過の中で現在行なわれている発光分 光分析の装置設計に伴う分析技術上の問題が明らかにさ れた. この点は本研究の所期の目的とははずれる面むあ るのでここでは簡単に紹介しておくにとどめるが，現在 鉄鋼のカントバック分析で採用している Fe II 2714·4 の内標準線には問題があるという知見を得た.すなわち その対象元素により効果が異なることである.

本来内標準線法は励起・発光過程における变動を内標 準線の強度変化により補正し，その影響が検量段階にお よばないよう監視するというすぐれた方法である.

したがつて励起・発光過程における変動があつた場合 にそれに追随できないような内標準線を採用することは 然意味であり，誤差を大きくする原因ともなる.

この実験においては，とくに異常放電を対象としたと きの内標準線を検討したのであるが，内標準線の種類に 
よりその影響度が異なることが明らかとなりそれは分析 スペクトル 線対間の励起電圧の差の関数として近似でき ることがわかつた.

すなわちスペクトル線強度を定義する理論式から計算 すると, 分析線対の励起電圧差の大きい場合, 光源の变 動を内標準線で補正することは困難であることの説明は じゅうぶんできる.

したがつて光源の変動に対する影響度を最少，あるい は無視するためには線対の励起電圧差を 0 近くにする必 要がある.

このことから分析線を少くとも中性原子線，イオン線 に区別しそれぞれの励起電圧に対応する内標準線を設定 することが必要となるであろう.

現在使用されている Fe II 2714.4 $\AA$ は分析線が，イオ ン線である $\mathrm{Mn}, \mathrm{Cr}, \mathrm{Ni}, \mathrm{V} \cdots \cdots . .$. よ゙の内標準線として は適当であるが， C, Si，P，S…..など中性原子線を分 析線とする元素については中性原子線の適当なスペクト ル線を用いることが望ましい。

なお現在新しい励起源として用いられつつある高速度 発光法についても若干の検討を行なつたが LVS 法とほ ぼ同様の傾向が認められたことを付記する.

\section{5. 結言}

銑鉄のカントバック分析法について，分析試料の性状 と, 異常放電現象との関連ならびにその分析值への影響 度を中心に検討を行なつた。

LVS 発光法を 適用した場合の 銑鉄試料の異常放電は 分析試料に起因するものであり，主としてグラフォイト 析出量が大きな要因となつていることを明らかにした。 異常放電は, black ring を伴わない放電痕を残し, 現在 実用されている分析条件では，積分時間を増加させると いう現象をもたらす。これらの現象はグラフォイト析出
が選択的放電を起こし放電点が集中しないためプラズマ 中の粒子分布が試料組成を代表しないことで説明できる ことを確認した．またこの異常放電を予備放電の延長で 規制しうることも確認できたが，実用分析作業としては 時間的な制約から操作の画一性を失うという久点もあ り，他の制御容易な条件を求めることが必要であること を指摘した．さらに現在の内標準線として用いられてい る $\mathrm{Fe}$ スペクトル線をすべての分析元素に共通して使用 することは分析䛊差の面からみて危険であることを実験 的に確かめた. これらの点については，本研究成果を含 め放電機構の解明がなされたのちはじめて, 試料性状に 影響されない新しい発光源の出現が可能となるという本 質的な問題解決に結びつく. 今後とも鉄鋼分析における カントバック分析の重要性は衰えないものとすれば，本 研究において得られた知見は分析試料と分析装置との両 面における技術的進歩にとつてなんらかの意義をもつも のと考える.

\section{文献}

1) 塚本，玉理，奥山：分光研究， 16 (1967) 1, p.7

2 ) 岡, 根本, 倉田: 分光研究, 9 (1961) 4, p. 201

3 ) 岡, 根本, 倉田: 分光研究, 11 (1962) 3, p. 116

4 ) 根本, 倉田：分光研究, 12 (1964) 6, p. 236

5 ) 浜口：分光研究, 12 (1963) 1, p. 30

6 ) 鹿島，久保田：分光研究，16 (1967) 3, p. 119

7 ) 広川：鉄鋼分析部会 第22回発光分析分析分科会 提出資料，No. 373

8 ) G. Andermann: Methods for Emission Spectrochemical Analysis, ASTM, (1968), p. 428

9 ) 萩原, 楢木, 田中: 分光研究, 15 (1966) 1, p. 1

10) J.R. BRown: Spectroscopy in the Metallurgical Industry, ed. by L. Bovey, (1963), p. 55 [Hilger \& Watts] 